\title{
A REPRESENTAÇÃO DO CONCEITO DE LIBERDADE EM "MERLI" - UMA PRÁXIS PEDAGÓGICA
}

\author{
Bruno Novaes* \\ José Pascoal Mantovani*
}

\begin{abstract}
RESUMO
Nesse artigo temos como objetivo analisar a representação do conceito de liberdade na primeira temporada da série "Merli", veiculada no canal de streaming Netflix. Nela, pretendemos verificar como o professor de Filosofia Merli Bergeron trabalha conceitos libertários e suscita reflexões críticas em seus alunos sobre os padrões de convívio socialmente impostos pelas instituições primárias e secundárias. Ao mesmo tempo, pretendemos abordar a personalidade do professor, discutindo sobre o convívio que ele mantém com os colegas de trabalho e seus alunos, assim como em sua vida particular, para visualizarmos se, de fato, ele pratica aquilo que discursa aos estudantes durante suas aulas. Haverá um foco maior na relação dele com o aluno Ivan Basco, que sofre com agorafobia e recebe aulas particulares de Merli para superar sua situação de isolamento. Em um primeiro momento, com caráter
\end{abstract}

* Bruno Novaes Araújo, bacharel e licenciado em Ciências Sociais pelo Centro Universitário Fundação Santo André. Especialista em Ensino de Geografia pela PUC-SP. Mestre em Ciências Humanas e Sociais pela UFABC. Doutorando em Ciências Humanas e Sociais pela UFABC, tratando sobre cinema e representação estética de lideranças políticas. Atua como professor em escolas particulares e na rede pública de São Bernardo, além de ser vinculado como professor modular à Pós-graduação em Diplomacia Empresarial da FMU. E-mail: bnovaisaraujo@yahoo.com.br

** José Pascoal Mantovani, graduado em Filosofia e Teologia, Mestre em Ciências da Religião e Doutorando em Educação pelo programa de Pós-Graduação UMESP sob a orientação do prof. Dr. Marcelo Furlin; coordenador do Grupo de Estudos 'DOMAINE: Foucault em perspectiva' na Universidade Metodista de São Paulo; prof. de filosofia no Ensino Básico e Superior. Título da Tese: Educar sem (de)formar: contribuições foucaultianas para a constituição narrativa do sujeito. E-mail: jose. junior20@metodista.br. 
introdutório, iremos discutir sobre a importância da discussão de liberdade na contemporaneidade. A seguir, exporemos conceitos formulados por diversos pensadores acerca do que é a liberdade e sua importância para a emancipação humana. A partir disso, serão abordadas informações básicas sobre a produção da série, como os diretores, veiculadores e atores envolvidos para, por fim, executarmos a análise dos capítulos do seriado e apresentarmos nossas considerações finais. Diversos teóricos pertinentes a esse trabalho serão utilizados na revisão bibliográfica. Como metodologias de análise fílmica usaremos, para verificação estrutural do filme, a metodologia de análise fílmica de Manuela Penafria (2009) e, para visualização das formas simbólicas, a Hermenêutica de Profundidade, proposta por John Thompson em "Ideologia e Cultura Moderna" (2002).

Palavras-chave: Liberdade; Merli; Educação; práxis; Representação

\section{INTRODUÇÃo}

Até que ponto a liberdade não passa de uma ilusão que persiste no imaginário do sujeito? Ser livre é realizar os mais variados desejos? É ser compulsivo? O niilismo é a pura representação do sujeito livre, da representação de sua força de potência? Ou será que a liberdade não passa de uma ficção, tal como uma série de TV, em que há projeção do ideal, mas que é inalcançável como práxis. A discussão em torno do tema da liberdade acompanha a reflexão filosófica e teológica, de modo que é possível elencar, ao menos, três conceitos básicos sobre liberdade:

Liberdade como autodeterminação ou autocausalidade, segundo a qual a liberdade é ausência de condições e de limites; liberdade como necessidade, que se baseia no mesmo conceito da precedente, a autodeterminação, mas atribuindo-a à totalidade a que o homem pertence (Mundo, Substancia, Estado); liberdade como possibilidade ou escolha, segundo o qual a liberdade é limitada e condicionada, isto é, finita. Não constituem conceitos diferentes as formas que a liberdade assume nos vários novos campos, como por exemplo liberdade metafísica, liberdade moral, liberdade política, liberdade econômica. (ABBAGNANO, 2007, p. 606) 
Seguindo a contribuição de Abbagnano, define-se, portanto, a liberdade a partir de três ideias básicas: a ideia de liberdade como absoluta e incondicional, de modo que não há graus ou limitações ou graus, a segunda compreensão da liberdade como necessidade e, por fim, a liberdade como medida de possibilidade, portanto, escolha motivada ou condicionada. A tensão inerente aos três conceitos é como o sujeito irá interagir nesse imbróglio de constituição de si, pois, pensar a liberdade é pensar a essencialidade do próprio ser.

Diferente dos animais irracionais que estão condicionados ao instinto e a luta pela sobrevivência diária, o ser humano tem a condição de transcender as molduras dos impulsos fisiológicos e dar significado e sentido para o cotidiano. Em vias marxistas, mais do que encontrar formas para sua sobrevivência, o sujeito transforma a si e o mundo em que está inserido por meio do trabalho que carrega rudimentos tanto objetivos como subjetivos. A ficção que acompanha o sujeito é sua pré-disposição em ser inacabado.

Nessa direção, pode-se aferir contribuição significativa, ao que se refere a liberdade, do filósofo Etiene de La Boetie. 0 filósofo francês destacou que a liberdade não é algo herdado é, em primeiro lugar, desejado e, posteriormente, conquistada, como Boetie destaca: "a liberdade é a única coisa que os homens não desejam; e isso por nenhuma outra razão (julgo eu) senão a de que lhes basta desejá-la para a possuírem; como se recusassem conquistá-la por ela ser tão simples de obter" (2006, p. 9). Nota-se que nessa alusão de Boétie há, segundo Toneti (2009), um paradoxo: ao mesmo tempo que o sujeito não desfruta na liberdade, ela, por si só, é fácil de ser adquirida, basta ser desejada. A falta de vontade para ter à liberdade é que faz do sujeito um ser ignóbil quanto a liberdade. Desejar a liberdade não é um processo instintivo ou biológico, é, aliás, um processo de racionalização e subjetividade. Portanto, aprende-se a desejar a liberdade.

Nestas vias de entrelaçamento - racionalização, subjetividade e liberdade - é possível dialogar com o arcabouço teórico de Michel Foucault que é por meio da liberdade que o ser sai da condição de objeto para sujeito, bem como o poder se transforma em dominação. Para Castro, "a noção foucaultiana de liberdade situa-se, em primeiro 
lugar, no abandono desse mito humanista de uma essência do homem. A liberdade foucaultiana não é da ordem da liberação, mas da constituição" (2016, p. 246).

A liberdade, nesta mirada, não é uma utopia, ou seja, o paradigma do lugar adequado, o "tópos" em que o sujeito é lançado pelos movimentos naturais da vida; a liberdade é, em oposição a utopia, a condição de constituição de si mesmo, ação que o sujeito tem de si sobre si, em um caminho de conscientização dos interstícios existenciais que fazem do devir o mecanismo que caricatura a heterotopia do sujeito. É neste jogo de verdade e liberdade que o sujeito alienado solapa tal condição e possui a si mesmo. É o que Castro destaca, ao descrever que "o alienado moderno não é um possuído, mas um despossuído, precisamente de sua liberdade" (2016, p. 248).

Trilhar pela liberdade é buscar caminhos que fazem do sujeito não só possuidor de sua vida, mas ciente dos entornos deste processo constitutivo. Nessa trajetória, a disciplina e o ensino de filosofia pode ser significativo para apontar possíveis caminhos deste processo constitutivo. Considerando que a filosofia não é fator cativo aos sistemas formalistas, mas que parte das contingências da vida, do cotidiano, das ficções míticas que o sujeito se apropria para encontrar sentido para si, apresentaremos o ensino de Filosofia, a partir da série "Merli", como dispositivo de liberação e transformação de si. Antes, porém, faz-se necessário destacar características gerais da série, esforço este da próxima seção.

\section{1 - Merli: UMa série de filosofia Prática}

Apresentaremos, nessa seção, alguns dados importantes sobre esta série. Merlí Bergeron (Francesc Orella) é um professor de filosofia nada convencional, que precisa reorganizar sua vida pessoal enquanto tentar de todas as formas mostrar para as pessoas a importância da filosofia. No total, a série teve 40 episódios. Cada episódio leva o nome de um filósofo diferente. Criada e escrita por Héctor Lozano e dirigida por Eduard Cortés, Merlí estreou na Catalunha pelo canal TV3 em 2015 no horário nobre. 
Depois de ter seus direitos comprados pelo grupo Atresmedia em novembro de 2015, a série foi dublada em espanhol e exibida em outros territórios da Espanha pelo canal La Sexta entre abril e junho de 2016. Internacionalmente, a Netflix comprou os direitos de exibição da primeira temporada na América Latina e nos Estados Unidos em novembro de 2016. No Brasil, a série está sendo exibida pela Netflix desde 1o de dezembro de 2016. Encerrou-se com 3 temporadas, em $2018 .{ }^{1}$

Eduard Cortês (1959) dirigiu diversos filmes e curtas-metragens. Foi premiado como melhor diretor de novelas com o prêmio "Goya" por "La vida de Nadie" (2002). Foi indicado novamente a melhor diretor em 2005, dessa vez por longa-metragem, com o filme "Otros dias vendran" (2005). Recebeu diversos prêmios também por outros filmes que dirigiu, como "El payaso y el Fuhrer" (2007) e “!Atraco!" (2012). Dirigiu as três temporadas de "Merlí".

Francesc Orella (1957) é ator de cinema, teatro, novelas e dublagem. Seu primeiro filme foi "El puente de Varsovia" (1989). Mais tarde atuou na série "Estacion de Enlace" (1994) e em "Secretos de Família" (1995). Em 2015 passou a ser parte do elenco da série "Carlos, Rey Imperador". Ganhou em 2008 o prêmio "Max" de melhor ator protagonista pelo filme "Um enemigo del Pueblo" (2007). Por Merlí, ganhou o prêmio "Zapping" em 2015 de melhor ator em diferentes dialetos e, no mesmo ano, venceu o prêmio "Iris" por melhor interpretação masculina. ${ }^{3}$

\section{2 - Metodologias de AnÁlise dos Capítulos do SERiado}

A Hermenêutica de Profundidade é uma ferramenta teórica e metodológica que permite analisar o contexto sócio-histórico e espaço temporal do objeto de estudo. Essa ferramenta fornece diversas opções, como análise discursiva, de conteúdo, semiótica ou qualquer outro padrão. A ideologia, por sua vez, pode ser analisada através da interpretação das formas simbólicas. Contudo, ela supera as formas

\footnotetext{
Informações extraídas de https://www.imdb.com/title/tt4580372/

Informações disponíveis em https://www.imdb.com/name/nm0181525/

Disponível em http://www.adorocinema.com/personalidades/personalidade-63192/ filmografia/
} 
tradicionais de ideologia, pois traz como inovação a necessidade de propor sentidos e discuti-los, podendo interpretá-los como ideológicos. Trata-se de fazer uma análise qualificada da realidade apresentada pelas formas simbólicas. Segundo Thompson (2002), tal metodologia, resumidamente é "[...] o estudo da construção significativa e da contextualização social das formas simbólicas” (THOMPSON, 2002, p. 363). A Hermenêutica de profundidade segue algumas etapas, que podem ser resumidas como análise sócio-histórica, que consiste na análise das situações espaço-temporais; a segunda fase é a análise discursiva; e, por fim, a última etapa, que é a ressignificação da forma simbólica.

O método de análise fílmica proposto por Manuela Penafria (2009), por sua vez, complementa o método hermenêutico de Thompson (2002) e visa fazer uma análise interna do filme. Para isso, ela propõe quatro etapas. A primeira etapa refere-se à apresentação das informações, como Título, ano, país, gênero, duração, diretor e distribuidora. A segunda etapa é decompor o filme a partir da dinâmica da narrativa. 0 procedimento adotado nesse trabalho foi decompor 0 filme por cenas selecionadas que apresentem formas simbólicas que expressam a representatividade dessas lideranças políticas no contexto do filme e para além dele. Essas cenas foram analisadas a partir dos discursos presentes nos diálogos das cenas em questão, bem como também serão descritos planos de cenas, trilha sonora e outros fatores que acompanhem a transmissão dessas formas simbólicas. A terceira etapa é chamada por Penafria (2009) de "pontos de vista". Os capítulos foram analisados nesse trabalho pelo sentido ideológico, com o intuito de verificar nas formas simbólicas o enquadramento que o diretor fez do conceito de liberdade. As etapas dois e três foram feitas ao mesmo tempo. A última etapa da análise fílmica proposta por Penafria (2009) é a seleção de cenas principais dos capítulos. Aqui, serão selecionadas aqueles que melhor ilustram o debate de liberdade existente nos capítulos selecionados.

Como a temporada é composta por treze episódios, para melhor se enquadrar em um artigo acadêmico selecionamos quatro episódios que melhor trazem o debate proposto nesse trabalho. São eles: 
Episódio 1 - Os Peripatéticos;

Episódio 2 - Platão;

Episódio 7 - Foucault;

Episódio 13 - Nietzsche.

\section{3 - Análises dos capítulos selecionados}

A seguir, apresentaremos a análise dos capítulos selecionados, já propondo uma reflexão que tangencia o tema da liberdade, como proposto por este artigo.

\subsection{Episódio 1 - Os Peripatéticos}

Merlí Bergeron se encontra desempregado, sendo despejado de sua casa e recebe da esposa a notícia de que ela começará a trabalhar em Paris, logo ele deve cuidar do filho adolescente Bruno, o qual ele abandonou ainda quando este era muito novo. Merlí está enciumado por que sua ex esposa esta namorando e assustado pela responsabilidade de cuidar de seu filho. Não quer se sentir preso pelas obrigações da paternidade, embora não admita abertamente. É um sujeito um tanto quanto rabugento e sistemático em um primeiro instante.

A entrada da série chama a atenção. São folhas de livros com diversos escritos de pensadores, com uma mosca circulando, simbolizando o incômodo da reflexão que Merli desperta, que tira os alunos e outros da zona de conforto e a coruja, símbolo do conhecimento que ele visa despertar e é bem-sucedido. As moscas em ato sexual remetem às várias aventuras de Merli com algumas parceiras ao longo da série, já que ele se mostra um conquistador.

Merlí é obrigado a viver com a mãe, demonstrando certa frustração, preso em seu próprio fracasso. Agora, além de conviver com seus próprios problemas, terá de cuidar de um filho jovem. Entretanto, recebe um alento logo a seguir: arruma um emprego como professor substituto de Filosofia numa escola pública catalã.

Ao chegar na escola, se estranha com o professor Eugeni Bosch e resiste a conhecer novos colegas na sala dos professores, dizendo ao 
diretor Toni que prefere manter distância, mas é forçado a se apresentar. É um Merli que tenta resistir a determinadas convenções sociais no ambiente de trabalho, mas está amarrado a certas condutas socialmente esperadas dentro da instituição em que atua. Ao entrar na sala de aula, seu filho Bruno descobre que será seu aluno e se envergonha de imediato. Merlí mostra um estilo provocador e questionador, fora dos padrões esperados. Consegue chamar atenção de Pol, aluno repetente, que se identifica quando ele diz que foi despejado e ri, já que também é pobre. Merlí mostra felicidade por estar na sala de aula, se sente livre e ri dos seus próprios fracassos pessoais, se realiza ao conquistar a atenção dos alunos e ao quebrar o padrão de ensino de um modelo educacional que criticará ao longo da série, inclusive abordando filósofos fora do programa proposto pelo Estado espanhol.

Merlí se encanta com a professora Laia, de Inglês, pela beleza e juventude. Ela namora Albert, professor de Educação Física. 0 filósofo flerta com ela, que resiste. Contudo, Merlí pega um cachorro de doação e leva à escola dizendo que não tem como conduzi-lo ao veterinário e ficar com ele. Laia se encanta e o ajuda. Eles acabam juntos no apartamento dela e mantém relação sexual. Merlí se mostra meticuloso, ardiloso e pouco ético, já que ela namorava com um colega de trabalho. Se sente livre para romper com a culpa judaico-cristã, como repetirá ao longo da série, e se entrega a seus desejos. Supera suas frustrações (que, aliás, finge não ser atingido por elas) com a conquista de mulheres que deseja, mesmo que isso resulte em problemas. 0 exercício de sua liberdade sexual serve para livrá-lo das prisões cotidianas do fracasso em que se encontra na sua vida financeira.

Merlí descobre que Eugeni Bosch daria aulas para Ivan Blasco, aluno que sofre com agorafobia. Ao encontrar o endereço do aluno, faz uma visita a ele, que mora com a mãe, extremamente preocupada e entristecida com a situação de seu filho único. Ivan se nega a abrir a porta para ela, que decide ir trabalhar, pois Merlí passou a conversar com o rapaz. Ele passa algum tempo falando sobre o filósofo Diógenes, que execrava os padrões sociais que aprisionam Ivan, critica Eugeni por seguir muitas regras e, quando estava em vias de desistir, o aluno decidiu abrir a porta para ele. Esse é o primeiro contato dos dois cara a 
cara. Ivan tem cabelos que cobrem seu rosto. Não fala, é extremamente tímido e triste com sua aparência. Contudo, a porta aberta simboliza a primeira vitória de Merlí nessa relação. É a abertura da porta para o conhecimento, que servirá para a superação dos traumas e do enclausuramento que aflige Ivan e, por consequência, sua mãe. Ao abrir a porta, Ivan começa a ser livre para experimentar o mundo.

A cena principal é aquela em que Merli leva sua sala para a cozinha da escola, por compará-la metaforicamente com o cérebro, que alimenta a alma. Ao tirar os alunos da sala, o filósofo quebra o protocolo de estar constantemente nela, propondo um ensino mais livre. Ao compara-los com os peripatéticos, assunto da aula, ele provoca os alunos a pensarem de forma mais livre e, para isso, mostra que todo ambiente pode servir de estímulo ao pensamento e reflexão. Com isso, ele estimula Pol Rubio a pensar se todos podem pensar, o que o agrada. Todavia, diz ao aluno em questão que ele foi criticado por Eugeni, o que revolta o rapaz que mais tarde reclama ao diretor. A liberdade de Merlí o estimula também a provocar um opositor quebrando padrões éticos de conduta na relação professor-professor e professor-aluno, pois para se aproximar dos estudantes ele denigre colegas. Isso mostra que Merli não é totalmente livre como pensa: essa forma simbólica denota que ele está preso a uma necessidade constante de aprovação que o leva a atacar seus próprios colegas. Ele tem a necessidade constante de se sentir querido, já que está essencialmente frustrado em vários campos de sua vida particular.

No final do capítulo, ele e Bruno se conectam mais, apresentam maior profundidade na relação pai e filho. Bruno se incomoda com o fato do pai se comportar como um adolescente. Merlí se contrapõe, dizendo que ele terá de acostumar com seu jeito. Dá um celular novo ao filho, numa clara tentativa de comprar a atenção do rapaz, algo típico da Sociedade de Consumo contemporânea, quando pela falta de tempo e proximidade buscamos fornecer mercadorias aos queridos por nós como uma forma de desculpa e refúgio de nossa incapacidade de nos conectarmos efetivamente a quem amamos. Bruno aceitou a imitação chinesa, daí Merli diz a ele que quer um filho crítico e aberto a experimentação. Porém, a ferramenta que usou para a aproximação do filho 
nada mais é do que aquilo que efetivamente aprisiona os indivíduos a seus isolamentos: o celular, ferramenta que pode ser usada para aquisição e propagação de conhecimento, mas também aprisiona as pessoas no mundo virtual, distanciando-os do calor do olho a olho, da proximidade física. Logo, por mais que tente, Merli é tão livre quanto imagina ser? Mesmo que tente quebrar padrões institucionais e de relações pessoais do cotidiano, ele não tenta criar réplicas de si em seus alunos e utilizar ferramentas de possível aprisionamento, como a conquista de mulheres mais jovens ou mercadorias como o celular, para superar supostamente as tais amarras sociais que o levam a sentir-se frustrado, mesmo que não admita?

\subsection{Capítulo 2 - Platão}

O capítulo se inicia com Merlí em sala de aula falando sobre amor platônico. Á medida que a aula se desenvolve, Bertha Pratz e Pol Rubio conversam. Ela o chama para sair, ele não quer mais por não estar apaixonado por ela. É clara a referência sobre a idealização de Bertha sobre a relação que tem com Pol, um amor não correspondido. Mesmo que não saiba, as aulas de Merli são enquadradas pelo diretor da série de forma a fazerem sentido na vida cotidiana dos jovens, para mostrar a utilidade prática da filosofia. A seguir, Merlí é chamado por Toni e repreendido por ver Ivan sem autorização. Com raiva de Eugeni, que o entregou ao diretor, ele propõe aos alunos da sala trapacearem no concurso literário, escrevendo uma redação de cunho erótico baseada em amor platônico, feita coletivamente, mas assinada apenas por Bruno.

Bertha mente a Pol dizendo que sua menstruação está atrasada. Pol se desespera, a notícia se espalha porque Tania não guardou segredo e Bruno espalhou. Mais tarde, Pol descobre a mentira e tenta cobrá-la com grosseria. Entretanto, ela alega que ele a enganou e, por isso, não havia razão para ele se irritar, pois apenas pagou na mesma moeda. Essa conversa denota a libertação de Bertha dessa relação platônica, da superação de uma relação com um indivíduo que se mostrou machista e aproveitador. 0 revide denota um aprendizado para que Pol se coloque no lugar dos outros e pense antes de enganar as pessoas sentimentalmente. Bertha se sente livre, Pol aprisionado em 
seu machismo e necessidade de afirmação. Na realidade, Pol está preso em um amor platônico por si mesmo. Imagina ser o tipo de homem ideal: belo, convincente, insubstituível, que pode conquistar a todas as mulheres e descarta-las como se nada significassem. Está imerso em seu próprio ego.

É necessário salientar que a coruja sempre aparece em cenas que denotam a passagem de tempo de forma mais significativa da série, simbolizando a aprendizagem e sabedoria sendo acumulada por todos os envolvidos na narrativa.

Eugeni tenta dar aula na casa de Ivan, mas ele não abre a porta. Quando o professor desiste, Merli aparece atrás de Ivan dentro de casa, motivando-o a repelir Eugeni. Mais uma vez Merlí quebra regras por acreditar que é o único capaz de fazer Ivan se livrar de seu problema, justamente porque ele, enquanto professor, não segue padrões. São esses padrões que aprisionam Ivan, que opta pelo isolamento exatamente por não ser capaz de segui-los. Logo, por se sentir livre desses tipos de amarras, Merlí considera que pode libertar Ivan do trauma de não conseguir também segui-las.

Ao receber Pol na sala de castigo por agressão a Bruno em decorrência de um desentendimento, Merlí percebe que pode usar tal espaço para atender alunos com dificuldade na matéria, ressignificando aquele ambiente como fonte de aprendizado, não como punição. Dessa forma, também se afastaria de outros colegas para poder atuar com liberdade, sem fiscalizações de Eugeni. É uma tentativa clara de se distanciar de amarras da instituição e introduzir uma nova práxis pedagógica. Embora Toni apresente a princípio resistência com a ideia, acaba se deixando convencer.

A cena principal ocorre na casa de Ivan. Merli usa o mito da caverna para relacionar com a agorafobia que acomete o rapaz. Usando materiais diversos na casa e algumas pequenas estatuas de pensadores, ele explica os conceitos a Ivan e o encanta, prometendo-o que o tirará daquela caverna. Essa aprendizagem significativa, motivada justamente pela liberdade que Merli encontra longe das amarras institucionais dialoga com a realidade de Ivan, estimulando a aluno a refletir sobre sua condição e começar a questionar sobre liberdade e autonomia. Apesar 
de ações anti-éticas para ali chegar, o filósofo consegue provocar Ivan. Se é o melhor ou o único caminho, cabe a discussão, mas inegavelmente ele alcançou sucesso naquele instante.

Por fim, ocorre o discurso literário e Bruno, representando a sala de forma não oficial, recebe o prêmio como segundo colocado. Merli sobe ao palco e fala que a redação foi escrita coletivamente, exaltando o trabalho em grupo. Apesar da indignação de Eugeni e Toni, a redação premiada e o trabalho em equipe demonstram um projeto bem feito e alunos estimulados pela literatura e filosofia, o que não apaga mais uma vez uma atitude agressiva do filósofo em relação a seu colega. 0 sucesso da práxis pedagógica é inegável, o exercício da liberdade e o aprendizado em romper com os padrões é alcançado, entretanto o preço é alto e Merli está mais uma vez aprisionado a seu ego e a vontade constante de ser querido pelos adolescentes. Ele envergonha Bruno ao subir no palco e contar o ocorrido. O jovem se vinga e conta a Albert sobre Merli e Laia. Merli é agredido por Albert. 0 filósofo não está livre das consequências, por mais que tente não ser atingido por elas.

Como forma de se desculpar, mais tarde Merlí presenteia Bruno em casa com o livro "O Banquete", de Platão, fazendo referências às várias formas de amar, estimulando seu filho a pensar sobre sua própria sexualidade, considerando que Bruno é homossexual não assumido. O pai estimula seu filho a se libertar sexualmente, dilema que será vivenciado por Bruno até o fim da temporada aqui analisada.

\subsection{Capítulo 7 - Foucault}

Merlí e Gina, mãe de Gerard, vivem uma relação às escondidas. Gina atua na Associação de Pais e Mestres da escola e decide, junto ao filósofo, propor um passeio dos alunos à Cosmocaixa, um local de exposições científicas no qual ela trabalha.

No início do episódio, Merli comunica aos alunos que tal passeio permite o diálogo entre Ciências e Filosofia e que deseja que todos participem da atividade extraclasse. Os alunos perguntam se Ivan Blasco também irá. Um debate se inicia acerca da personalidade de Ivan, visto por muitos como "anormal". Merlí contesta o status de normalidade e para isso passa a falar de Michel Foucault. Ao comentar sobre a ho- 
mossexualidade do francês e como isso influenciou em seus estudos contestatórios aos padrões socialmente impostos, Bruno se incomoda por achar que o pai o está provocando. Os dois se desentendem e Merlí o expulsa da sala. Essas cenas demonstram que Merlí está preparando terreno para a volta de Ivan, revelando uma estratégia de reinserção do aluno ao cotidiano escolar, conscientizando os colegas da importância de respeitarem a diversidade. Por outro lado, seu filho ainda se encontra preso no que diz respeito a homossexualidade e se rebela ao pensar que o pai não está respeitando seu direito de discrição. Merlí, que contesta toda e qualquer demonstração de autoridade por ser parte de imposições de padrões sociais, usa de seu poder institucional para tirar Bruno da sala, por considerar que seu filho o afrontou. Não seria essa uma contradição? Usar do poder de professor, algo tradicional e padronizador, para impor sua autoridade em sala? Para um professor convencional ou mais apegado às normas, talvez não seria, mas para Merlí, contrário e rompedor das tradições, soa estranho.

Joan vivencia problemas com o pai controlador em sua casa. É aluno tímido e pouco a pouco vai se soltando e querendo experimentar o mundo, muito em conta pela influência das aulas de Merlí. Seu pai é um advogado bem-sucedido que quer impor tal profissão ao filho. Não felicita Joan pelas boas notas, alega que é apenas obrigação. Com raiva, ele quebra a maquete do pai. Quando o jovem decide colocar um piercing, o pai, especialmente, se mostra bem agressivo e indignado. Joan não cede e os dois gritam um com o outro. 0 estudante está em busca de maior autonomia e contesta o poder do pai controlador que o impede de ser livre e fazer suas próprias escolhas. Seu pai é exemplo de indivíduo castrador que culpa o professor provocador devido ao fato de estar perdendo o monopólio da atenção do filho. Joan, por sua vez, está decidido a romper com a atitude cerceadora do pai, que reprime toda e qualquer tentativa dele de conhecer o mundo a partir de suas próprias reflexões. A práxis pedagógica de Merlí está convulsionando as estruturas desse lar familiar conservador. Mais uma vez, portanto, a filosofia ganha contornos de praticidade na narrativa da série, influenciando diretamente no crescimento intelectual e na autonomia do indivíduo ali enquadrado. 
Pol Rubio está aprisionado pela sua própria condição financeira: eis seu grande drama pessoal. Vive em uma casa bem simples. 0 irmão trabalha e está sem condições de pagar energia elétrica. Pol acaba vendendo sua moto, apesar de muito resistir, para quitar as contas. À certa altura, fala para Merli que não vai ao passeio e não terminará os estudos. É convencido do contrário pelo filósofo, que mostra o resultado positivo que ele tem na prova. 0 jovem tem uma relação muito próxima com a avó, já que a mãe falecera anos antes. Dormiu no colo da senhora em certo momento do episódio. Quando acorda percebeu que ela estava morta. Se sente só, perdido, era o seu último grande vinculo sentimental, pois é distante do pai e do irmão. Aqui se percebe que Pol é extremamente sensível, mas mantém uma postura de marrento para não demonstrar fragilidade ou obter sinal de dó ou piedade de ninguém. É orgulhoso e se aproveita de sua facilidade para conquistar mulheres e descarta-las como uma forma de suprir o vazio com a perda da mãe, o descaso do pai e irmão com ele e fugir temporariamente das angústias que a pobreza gera em seu dia a dia. Pol está amarrado à prisão gerada pelas privações e por estar em desvantagem financeira diante de todos seus colegas de sala. Ele se identifica com Merlí e encontra no filósofo de certa forma o exemplo de pessoa que não abaixa a cabeça mesmo diante das adversidades, daí tamanha admiração pelo professor.

Bruno também é enquadrado como alguém que está profundamente frustrado. Reprimir sua sexualidade tem feito ele atacar o professor Santi devido a obesidade. 0 professor tenta conversar com ele, indagando-o por sua atitude hostil. Revela que ser gordo em um mundo que cultua a aparência é difícil, mas que não se sentirá culpado por ser quem é. Isso incomoda Bruno, que reage com aparente indiferença, mas inveja a Santi, pois ele é capaz de viver bem com o fato de ser diferente, resistindo às padronizações sociais, contestando o que é imposto como "corpo normal". O jovem ainda não consegue superar seu complexo devido a sua sexualidade, está preso no preconceito que sente por si mesmo. Além disso, está apaixonado pelo galanteador Pol Rubio, com quem constantemente se desentende por ciúmes e não revelar seu amor reprimido. Acaba se afastando do amigo, com quem sempre manteve proximidade. Mais tarde, é convencido por Merlí a ir 
ao enterro da avó de Pol. Ao chegar lá, encontra o amigo triste, fragilizado, e acaba consolando-o com abraço fraternal. Assim, Bruno se livra temporariamente de seu orgulho, se sentindo melhor consigo mesmo e com o mundo a sua volta. É uma redenção temporária, mas a prisão que impõe a si mesmo permanece já que ainda reprime sua sexualidade.

Ao retomar Foucault em sala, Merlí motiva os alunos a falarem de suas esquisitices. Assim, ele visa mostrar com sua práxis pedagógica que a normalidade é uma invenção, uma tentativa de padronização e controle que impedem o desenvolvimento pleno das potencialidades humanas e o alcance da felicidade. Os alunos revelam suas excentricidades, o que permite a ele dizer que todos somos "anormais" e por isso não deve haver hostilidade ou desdém em relação ao Ivan quando ele voltar. Ao conseguir o comprometimento de todos em sala, Merlí consolida o ambiente para o retorno do aluno. Só faltava convencer o jovem que a essa altura já saia à rua acompanhado de Merlí e mantinha com ele maior relação de confiança e proximidade. Faltava pouco para a superação da agorafobia e a maior vitória acadêmica de Merli na temporada abordada nesse trabalho.

O drama de Merlí, por sua vez, está nas responsabilidades da paternidade, de não conseguir se aproximar do seu filho, pois nunca agiu com as preocupações que se espera de um pai. Sua mãe, Calduch, diz que Bruno tem ciúmes da atenção que ele dá para Ivan em detrimento de seu próprio filho. Merlí, teimoso, resiste a aceitar, mesmo com sua namorada Gina também lhe dizendo o mesmo. Ele se dá conta da falta com o filho quando percebe que nunca foi ver o garoto dançar. No final do episódio, na cena principal aqui escolhida, ele finalmente vai até a academia de dança onde Bruno estuda e se emociona ao vê-lo bailar. Essas cenas trazem formas simbólicas, como a música clássica de fundo, os movimentos sensíveis de Bruno, bailarino habilidoso e o choro de Merlí, claramente sensibilizado por descobrir o talento do filho. Se antes o filósofo não queria se prender às responsabilidades da paternidade, ele passa a escolher as amarras de ser um pai, cuidando de alguém que indiscutivelmente precisa dele. Merlí já sabe que Bruno é homossexual e está apaixonado por Pol. Compartilham segredos, estão muito mais próximos. Sem perceber, Merli decidiu se prender, 
pois a liberdade plena que escolheu em outros momentos o afastou de alguém que ama muito. A liberdade como possibilidade ou escolha está evidenciada aqui em toda sua finitude. Não será plena, pois Merli está preso definitivamente, por escolha, às obrigações com seu filho.

A liberdade é retratada esteticamente como uma relação de escolha e consequência. As questões existenciais, as possibilidades e escolhas vão denotando as essências socialmente construídas das personagens enquadrados. A liberdade apresenta limites, pois o mundo retratado na série impõe demandas a cada um dos indivíduos ali retratados que escapa às suas vontades. Por isso, se libertar plenamente é impossível e, parcialmente, também não é dos exercícios mais fáceis.

\subsection{Episódio 13 - Nietzsche}

0 professor Santi morreu repentinamente. Sua esposa, que também é docente na escola, está arrasada, cuidando dos preparativos do velório. Enquanto isso, Merlí conversa com os alunos sobre a morte e como ela nos atinge. Eles o escutam com atenção. Antes de falar de Nietzsche e a morte de Deus, ele faz um sorteio de quem varrerá a sala mais tarde. Não há nomes nos papéis que aparentemente seleciona, e informa que Joan e Mônica farão juntos tal tarefa. Merlí já sabe a essa altura do interesse de Joan por Mônica, assim como também está ciente que Gerard, filho de sua namorada, também está apaixonado pela aluna. Ele interfere diretamente nas relações desses jovens, se sentindo no direito de manipula-los de forma a aproximar aqueles que considera mais aptos a estarem juntos. O filósofo está impondo sua percepção e vontade na vida amorosa dos jovens. Nesse aparente "empurrão inocente" para a aproximação dos alunos, ele parece exercer um complexo de Deus, ideia essa que combaterá ao expor os conceitos de Nietzsche, de quem confessa ser muito adepto. Não seria essa mais uma contradição de Merlí? Ele está deixando seus alunos livres para crescerem ou tenta criar um mundo de acordo com sua vontade e onipresença?

Ao falar de Nietzsche, ele explica aos estudantes sobre a ideia de morte de Deus, a superação da necessidade humana de ser comandada e responder a um ser superior. Matar Deus seria uma libertação. Aproveita o gancho para "libertar" os alunos para irem prestar condolências 
a Glória, esposa de Santi. Saem sem autorização e vão até o local em que ela se encontra. Lá, Oliver, aluno novo e assumidamente homossexual, encontra o pai, dono da funerária. Conversam sobre a necessidade de o jovem ter paciência com a depressão da mãe, resultante da trágica morte do irmão dele. Oliver é alegre, cheio de vida, mas se sente refém do clima de tristeza e lamúrias em sua casa. Quer ser livre para viver sua sexualidade e experimentar o mundo, mas se sente preterido pela memória do irmão, por isso vive em conflito com os pais.

Bruno está muito triste com a morte de Santi, pois sempre tirou sarro da obesidade do professor. Não acompanha a sala na ida à funerária. Acaba mais tarde se desentendendo com Gerard em sala, pois este diz que ele sempre sacaneava Santi. Ao agredir o colega, Bruno acaba expulso da sala por Eugeni. Merlí toma ciência do fato e encontra o filho em casa, que justifica seus atos culpando a todos. Leva um tapa na cara do pai, que o manda se responsabilizar por seus atos e assumir as consequências de ter ofendido um cara decente como Santi. Merlí usa de uma atitude dura e bem convencional (também condenável por ser uma agressão) para dar uma dura lição ao filho sobre ações e responsabilidades. No âmbito familiar, mais especificamente na relação com o filho se mostra prático em muitos momentos, o que foi funcional, pois Bruno refletiu e acabou visitando Gloria e pedindo perdão. Ela aceita e o jovem confessa a ela ser homossexual. Na escola, dias depois, encontra Oliver e pergunta a ele como se sentiu ao assumir a homossexualidade. Depois da conversa, os dois passam a dançar e essa manifestação traz a simbologia de libertação de Bruno, que finalmente assume sua orientação sexual e rompe com qualquer receio que tinha em relação a si mesmo. Merlí funciona como inspiração para isso, embora seja duro para o filho orgulhoso admitir. A práxis pedagógica do filósofo não só o aproximou do filho, mas também o estimulou a se libertar dessa amarra torturante. Apesar de suas excentricidades, Bruno deve a seu pai o reconhecimento pela inspiração de ter gerado nele a vontade de ser livre e experimentar.

Joan e Mônica também necessitam resolver sua situação. Joan consegue se impor mais em casa, seu pai está mais flexível, muito pelo câncer que o atingiu. Logo, ele se sente mais confiante, mais autôno- 
mo. Gerard aparece em casa dançando com vassoura, imaginando ser a jovem que almeja platonicamente. Entretanto, Gery não conta que Joan, seu grande amigo, também está enamorado por Mônica e espera inocentemente que o jovem tímido o ajude. Ela está interessada em Joan, pois ele assumiu em uma festa em episódio anterior que gosta dela, embora estivesse alcoolizado, por isso teve coragem de dizê-lo. 0 estudante tenta falar do interesse de Gerard nela, mas rapidamente é repelido por Mônica, dizendo que ela lembra do que Joan disse na festa. Eles se aproximam e se beijam. Os dois se libertam do controle indireto de Gerard que, embora seja muito querido por ambos, estava atrapalhando o desenrolar desse romance. Gery está aprisionado pela sua timidez e incapacidade de dizer o que sente a Mônica, que se aproxima de Joan justamente pela coragem que ele teve de superar a sua timidez e dizer o que sentia. Os dois fazem acordo de manterem a relação em segredo. Tempos depois, quando Gerard tenta dizer o que sente a Mônica, ela diz que não quer relacionamento sério, omitindo dele o que vive com Joan. Agora eles voltam ao aprisionamento, pois não podem revelar o que vivem um com o outro de novo para não magoar o amigo. É uma relação de aprisionamento, libertação e aprisionamento, um ciclo vicioso que impede a vivência do sentimento compartilhado por ambos em sua plenitude, o que pode resultar num esgotamento precoce da relação.

Uma cena emblemática ocorre em sala de aula. Merlí retoma Nietzsche e seu combate ao servilismo. Diz que defende que todos sejam partidários dessa ideia. Pol rebate, dizendo que se isso for feito, ocorrerá mais uma padronização. Ele gosta da reflexão. Os alunos perguntam se ele será demitido por levar os alunos ao velório sem autorização. Ele informa que sim, pois Toni está irritado. Os alunos se articulam e entram na escola a noite. Picham a parede com um pênis e nele escrevem: "Merlí, você nos faz ter tesão." No outro dia, Toni e Eugeni aguardam Merli em frente a pichação e dizem que isso de nada servirá, pois será demitido. Ao inquirirem a sala sobre o autor, todos admitem ter participado. Toni insiste na demissão, mas os alunos adotam a estratégia irônica de pedir a demissão do filósofo, citando todos os conceitos que aprenderam, as reflexões ricas e a iminente 
volta de Ivan. Toni fica sem jeito e acaba por engolir Merli, que depois se mostra seu amigo. Essas cenas demostram simbolicamente a vitória de Merlí: seus peripatéticos o cultuam, querem ele, dependem dele. A pichação denota criatividade e articulação coletiva, capacidade reivindicativa e autonomia. Sua práxis pedagógica fortaleceu o ímpeto crítico dos alunos e contou a seu favor mais tarde. Todavia, devemos indagar: não estaria Merli, seguindo o próprio questionamento de Pol na aula, criando outros Merlís? Isso não seria uma padronização que contesta a padronização hegemônica para ela, mais tarde, com a superação da vigente, não se tornar a imposição socialmente majoritária?

As cenas principais ocorrem com Ivan Blasco e sua relação com os colegas. Na confraternização que antecede as férias, os alunos e Merlí estão em sala e ligam para Ivan ir até a escola. Ele hesita, mas toma coragem e sai à rua. A mãe acompanha de longe, emocionada e feliz. Ele corre e supera seu medo. Ao chegar na escola, é cumprimentado por Toni que está acompanhado de Eugeni, que vê a tudo atônito. Quando Ivan entra na sala, é felicitado pelos colegas, abraçado por todos, que respeitam as diversidades e as peculiaridades de Ivan. Os peripatéticos agora estão completos. A cena final é a sala de aula vazia, com a lousa escrita com os dizeres: “Bem-vindo, Ivan!”. Merlí conseguiu: Ivan deixou a caverna, seu aprisionamento e vai experimentar as incertezas do mundo. Seus alunos sonham e deixam sonhar, vivem e deixam viver. Ivan é parte de um projeto bem-sucedido de Merli, que educa Filosofia de forma prática. A Filosofia faz sentido, pois pensar liberta. Entretanto, novos desafios virão. Há mais dois anos de formação dos peripatéticos, uma vida de compromisso com Bruno, a necessidade de inspirar Pol e a urgência de superação de suas frustrações cotidianas. Merlí ainda mora com a mãe, mas tem um emprego que ama, uma relação sólida aparentemente com Gina e ganhou a confiança de Toni. Está livre o tanto quanto é possível. Eugeni é sua pedra no sapato, mas foi derrotado, sua práxis pedagógica se mostrou eficiente e agora tem seus alunos nas mãos. A merlinização segue a todo vapor, com todas as contradições que lhe são inerentes. 


\section{CONSIDERAÇõES FINAIS}

Merlí suscita diversas reflexões. Rompe sem romper plenamente. Pensa ser totalmente livre, mas escolhe certas ferramentas padronizadas para alcançar seus objetivos de incomodar e questionar os padrões sociais. Filosofa sobre a liberdade, mas não cita os limites que a cercam. Entretanto, vivencia-os intensamente. De certa forma, como foi com a paternidade assumida verdadeiramente durante a temporada, escolhe as responsabilidades e consequências que o aprisionarão no papel de pai. E descobre que isso o realiza, que é bom, pois como ser em constante construção, descobre que amar e compartilhar com seu filho o realizam como ser humano.

Esse filósofo começa como galanteador e acaba numa relação estável com uma mulher de idade próxima. Será amadurecer se padronizar? Merlí se tornou alguém que optou pela segurança, apesar de a todo momento estimular em seus alunos a experimentação e aventura? A liberdade limitada acabou encantando Merli, embora ele não admita?

A liberdade é uma construção social que encontra limites na própria estrutura socialmente legitimada e continuamente transformada. Jaen Paul Sartre já alertava sobre a necessidade de na vida nos equilibrarmos entre escolhas e consequências. Ao tentar fugir da padronização com sua práxis pedagógica, Merli pode construir uma nova padronização, pois seu ego o impede muitas vezes de enxergar as merlinizações que promove na mentalidade e na vida dos jovens. O que se diz aqui não é uma contestação às inovações ou ode ao conservadorismo, mas um alerta: os egos de tantos Merlís, contestatórios por excelência, com discursos que encantam e promovem reflexões válidas e novas propostas pedagógicas, podem por si só, quando vistos como únicas alternativas de condutas válidas, tornarem-se por si só tão arbitrárias como as tantas outras que costumavam contestar. Merlí é inspirador, humano e empolgante, mas também é contraditório e porque não dizer, repressor se mal interpretado, propagado e utilizado erroneamente.

Revista Páginas de Filosofia, v. 8, n. 1-2, p. 3-23, jan/dez. 2019 


\section{REFERÊNCIAS}

BOETIE, Etienne de La. Da servidão Voluntária. 2016.

CASTRO, E. Vocabulário de Foucault. São Paulo: Editora Perspectiva, 2016.

FOUCAULT, Michel. A Hermenêutica do Sujeito. São Paulo: Martins Fontes, 2018.

PENAFRIA, Manuela. Análise de Filmes: Conceitos e Metodologia (s). 2009. Disponível em: http://www.bocc.ubi.pt/pag/bocc-penafria-analise.pdf

THOMPSON, J. B. Ideologia e Cultura Moderna. Petrópolis: Vozes, 2002. 